\title{
Makeup Learning Model for Mentally Disabled Children
}

\author{
Ni Luh Putri \\ Universitas Negeri Manado \\ Manado, Indonesia \\ niluh_putri@ymail.com
}

\begin{abstract}
Makeup learning is a model for mentally disabled children of special needs kindergarten in norh Sulawesi. The purposes of this research were: (1) To describe the implementation of makeup learning in the extraordinary kindergarten, and (2) To create learning model which improves the skill of makeup. This research uses research and development procedure. This research used analytic descriptive method. The research data were collected by observation, questionnaire, interview, and documentation, which were then analyzed descriptively. The research's subjects were ten children and five teachers. The result of the research showed that the implementation of self-makeup learning on the beginning of learning activity was enable the teacher to prepare the children both physically and mentally to study, $(80 \%)$ achievement. The achievement of the main learning activity did not reach $69 \%$ yet, because the training material for self-makeup was not appropriate with the difficulty and the ability to learn for each student individually. The achievement at the closing lesson activity is $81 \%$ because the teachers were able to follow through by giving the exercise assignment to students at home individually $80 \%$. The process of developing a learning model begins with analysis and supported by various learning theories and principles of learning. The result of the development model is: (1) Direct learning model, (2) Direct learning model physically
\end{abstract}

Keywords — Learning model; self-makeup; mentally disabled

\section{INTRODUCTION}

In the extraordinary kindergarten, mentally disabled children have different ability in one class. Having children with diverse backgrounds and abilities in one class, the teacher needs to consider what each child needs to learn and how to learn well, discover how to make all children want to learn. The three obstacles of study together suppress the weak, prejudice, and discrimination. (Ichrom and Watterdal, 2004:20). Related to those things, in the inclusive classroom, the curriculum used is relevant to all children in terms of the material provided, how to teach it, how children learn, need to be considered that every child has different learning difficulties with each other. Mentally disabled children have difficulty in learning especially learn to makeup. This is due to the lack of intelligence in the mentally disabled children. Mentally disabled children show significant retardment in aspects of cognitive and social development. Learning very slowly and showing low achievement for all subjects, have difficulty in adaptive behavior that related to daily life skills (Ormrod, 2008:249). Mentally disabled is concerned with the problem of developing a low intelligence ability that damages the condition. In another sense, his ability to think is far from his age. Mentally disabled refers to a general intellectual function that is substantially below average along with behavioral adaptation and takes place in a period of development Drew, Logan, and Hardman (1986:5). The intelligence of mentally disabled childhood is below the average of the child in general. This is the reason they experience obstacles in learning and difficulty adjusting to their environment.

The field observation's result shows the implementation of makeup learning in the extraordinary kindergarten has not been implemented individually and has not paid attention to the characteristics of individual student learning difficulties, has not noticed differences in learning abilities and individual learning needs on the characteristics of early childhood ability of mentally disabled very diverse. Arum explains all educational professionals or educational personnel involved in the implementation of inclusive education in schools must understand that each student is unique, having individual needs different from each other (2005:120). Furthermore, Arum explains all educational personnel in the school should understand the individual needs of the students so that the services of general or mass education must be accompanied by services that are individual (2005:120-121).

The implementation of self-makeup learning in Extraordinary Kindergartens in North Sulawesi is not effective, because the teachers personally did not understand the student's needs and difficulties. Furthermore, they don't have sufficient knowledge and skills to serve mentally disabled students with various abilities and difficulties in learning. They also have not understood how to select and how to use which teaching methods, strategies, approaches, and techniques that will be used relating to the teaching material and the students' needs and difficulties in learning individually. It is actually related to the poorness of the teachers in designing and managing the learning method. Therefore, to overcome this problem, the teachers need to select the appropriate strategy. In addition to that, the teachers should have the training to develop the methods to support this effort. Joyce, WeilldanCalhoum explained that learning method is to help students gaining information, idea, skills, values, and thinking skills, also they can do self-actualizing to improve the learning ability easier and more effective (2009: 6). Self-Makeup skills by own selfare beneficial for each individual as it is one of the basic things to be independent. In order to increase the students' potentials 
and decreasing their drawbacks, the teachers should create concrete, systematic and individualized efforts that are to develop the self-makeup teaching method.

Due to the background, the questions for this research is how the implementation of makeup skill learning in TKLB in North Sulawesi is and how to design the teaching method to improve makeup skills through individual learning. This research aims to: (1) describe the implementation of makeup learning in TKLB in North Sulawesi, and (2) create the teaching method to improve the self-makeup learning through individual learning.

\section{METHOD}

This research is using the research and development procedures. The aim of this research is to develop self-makeup training. Brogand Gall (1989 : 782) said that the product which will be produced not only be in the form of text, movie study, learning program but also the model of learning. Based on what Brog and Gall's (1989: 782) statement product which support learning system to students to form the result of the learning model development. In further rise, Borg and Gall said that the learning model development is a form of research development of limited small scale (2003: 357). There are some steps to reach the aim of this research: doing the introduction of the study and doing the development of the study. This research held in extraordinary kindergarten in North Sulawesi started from April until August 2013. This research data collected using observation, questioners, interview, and documentation. Before using the collected data tools firstly it needs to test its validity and reliability, so we can get the data accurately. The objects for this research are five teachers and 10 5-6 years old children who are mentally disabled. The quality of the planning and implementation of the learning (RPP) and the evaluation result of mentally disabled children is the indicator of the implementation selfmakeup practice.

The qualitative data comes from the assessment and the result of observation of the self-makeup process, credibility test was done with long observation, the result of the observation is made from the descriptive analysis method. The data obtained from interview result and from critic and suggestions which is appropriate with the planning and implementation of the learning which is made by the teacher using the guidelines for the assessment of teacher's portfolio. The data analysis technic of this research uses content analysis and descriptive analysis. To discuss the teacher's planning and implementation content of learning (RPP), it is used content analysis, to appraise self-makeup learning process and teacher's opinion to the model, it is used descriptive analysis.

\section{RESULTS AND DISCUSSIONS}

The research finding shows that there are two things: (1). Things related to the implementation of self- make-up learning and (2). The development of self-make-up learning model result.
The result of the research shows (80\%) achievement at the beginning of learning. The teacher is already able to prepare the children physically and mentally to study. Dick and Carrey (2005: 43) explained that the form of learning strategy which can be used in implementing learning activity is pre-learning activity, presentation of learning material and follow-up activity. In the main activity, the learning achievement is 69 , it is not yet maximal because of the selfmake-up exercise material is not appropriate with the individual learning difficulty and the ability of every child. The teachers do not fully help the student taking the hairbrush, ask a student to hold their hairbrush correctly. If the student has difficulty in holding hair brush correctly, the teachers help them by holding their finger and then their arm, the achievement is only $65 \%$. The teachers do not ask the student to brush their hair begin from the top of the head to the bottom and the left hand organizes the hair, the achievement is $72 \%$. The teacher does not help the student when the student has difficulty in combing their hair, the teacher holds their arm then comb their hair together, the achievement of it is only $68 \%$. Runtukahu (2013: 73-74) prompting procedure is successful to be used by the teacher in increasing the student's adaptive behavior with a mild, moderate and severe disability. The prompt stimulus strategy is to give verbal instructions, to demonstrate the correct physical response of the prompt that there is physical contact between the teacher and the student such as the teacher holding the student's hand, and giving instructions with clues. Teachers do not train students combing hair step by step, every step is done repeatedly until students can actually do it on their own without the physical help, achievement $(66 \%)$. Teachers do not give the reward when the students can do the task either with the help or without help the achievement of it is only $70 \%$. Give reward immediately to every child who done their job. When the child can complete the assigned task, then the teacher asks for higher duty (Rochyadi and Alimin (2005: 186)). Methods used by teachers are not appropriate with the learning material, media, learning needs and learning barriers for each individual child, achievement of it is $71 \%$. Teachers give a less clear explanation because it is difficult to understand, teachers use simple sentence and single sentence which are less clear, the achievement is only $67 \%$. Attract students' interest in learning, motivate, and make fun learning, the achievement is $74 \%$. Teachers observe and record every step of combing hair that has not been and that has been done by children in the learning process which occurs less maximum, the achievement is only 62\%. Rochyadi and Alimin (2005: 154) explain students' learning progress should be measured regularly and periodically. The teacher should measure students' learning progress every day and use the evaluation result to make decisions in planning the next learning program. In the learning closing activity, the achievement is $81 \%$, because the teacher is able to give follow-up by giving the training task to students at home individually, the achievement is $80 \%$.

\section{A. The implementation of self- make-up learning}


The components of RPP made by teachers which are revised together indicate that corrected indicators on teachermade learning plan show: 1) Teaching materials are not yet adapted to the learning needs of each individual student and the formulation of indicators should be clear and complete. Moore (2005: 9-10) suggests an effective learning indicator is the quality of the implementation plan of learning, a conducive classroom environment, various learning techniques use, and done professionally.2) The planned learning materials have not been designed appropriate with the child's abilities, the learning material should be gradually designed and repeatedly given until the child can work on his own without physical help. This makes the child difficult to follow. Learning methods are not yet adapted to the material, 3) Learning activities have not been designed individually, according to the material, inappropriate with the formulation of indicators. The steps of teaching activities have not been systematically designed and have not been adapted to the needs and barriers of children's learning. Teachers do not motivate children by giving reinforcement, 4) the planned assignment and the way how to do the task should be clear. Therefore this research can be followed up with the required competence analysis that describes the abilities that need to be realized as a result of self-development learning subjects; especially self-make-up materials, to comb the hair. To determine the model design which will be generated, it needs to explain the ability or competence required and controlled by early mentally disabled children in following the lesson of self-make-up skills.

\section{B. The result of model development}

\section{1) The model of self-make-up learning}

The self-make-up learning model is a manifestation of the theory and principles of integrated learning in such a way as to shape the visual appearance of how learning is built on the basis of learning theories and principles. Abdurrahman (2003: 293) proposed a direct teaching program based on behavioral psychology, focusing on the direct instruction of specific skills chosen by the teacher. Arends (1998: 311) proposes a direct learning model aimed at helping students learn basic skills that obtain information that can be taught step by step. The design of self-make-up learning models applied in extraordinary kindergartens are, 1) structured learning environment. Behavior is formed as a result of the relationship between the individual and his environment. Therefore the environment becomes the determining factor in the formation of early mentally disabled childhood behavior. The arrangement of learning environments that can provide a positive stimulus laid out well to make behavior (learning outcomes) formed. Abdurrahman argues that the role of teachers in direct instructional programs is to design and to arrange learning experiences carefully to build pre-academic and academic skills. Various materials and activities are carefully designed to develop various skills. One of the contents of the skills activity program is self-help. Self-Make-up exercise is planned and done in a structured individually manner.

This learning model centered on the teachers, however, it involves early mentally disabled childhood by learning how to do self-make-up helped by the physical model, verbal instruction, and positive strengthening. These actions can be meant that learning environment is created and be oriented on tasks given to students and it also gives hope so that mentally disabled early childhood reach a good result on learning, 2) the learning approach management system and learning material. The method used by teachers are structured and formal, centered on teachers, learning management system ensure the students' involvement, learning strategy which is individually used, learning material suited by its need, the capability and difficulty owned by the early mentally disabled child. The media which is used is media suitable for children learning needs, 3) the theory which comes from expert become a base of learning activity which is taken from behavioristic as the source. Learning theory pointed out by Charles M. Reigeluth is used as a learning theory framework which consists of three learning variables, condition, method, and learning result which affect each other 4) the learning model development principle which becomes the base to create the learning skill model of self-make-up by creation of learning climate condition, student training, method variation, medium, and evaluation, so that mentally disabled early childhood student is capable to do selfmakeup without any helps and autonomous.

\section{2) Physical model}

The self-make-up physically learning model consisted of :

a. Learning model guide for teacher consists of model explanation, learning action plan, learning material resume for the teacher, and evaluation. Self-make-up learning model has several elements such are Purposes

- To create a learning condition which makes student's active role happens to explore new things related to what they are learning.

- To encourage the mentally disabled early childhood student to grow their motivation, make fun learning atmosphere so that mentally disabled early childhood student can give their attention into learning activity occurring.

- To be an evaluation model for the teacher to measure early mentally disabled childhood 
student learning to succeed in studying the self-makeup skill in daily life.

- To maximize student learning time in order to develop early mentally disabled childhood student autonomy, Syntagmatic. The step of self-make-up skill learning activity which will be arranged is suited with students' characteristic. The steps of learning made are

- A teacher delivers the competencies that have to be reached

- teacher demonstrates how to do selfmake-up by teaching student slowly, consequently, using physical, model, verbal instruction and positive strengthening

- The teacher helps a student to comb their hair and teach how to use face powder, ask the student to continue doing their task to the next step. If a student cannot finish their task, a teacher helps the student by holding their hand and together do the task from first until the last step (without physical help),

- Give feedback to the learning process and the result

- $\quad$ To give learning process evaluation by observing and recording step by step task that has already done and that have not finished by the mentally disabled student, f) to analyze early mentally disabled childhood student progress

- To do the evaluation of learning result by observing and recording all the step from the beginning until the end of the task which is already finished without a teacher's help, only by the teacher's instruction

- Evaluation and follow-up.

b. Management principle. The principle used in learning management running by the teacher is to give easiness to a student to study. teacher plays role to train student individually with or without help suitable with their competency, to give feedback toward student response, to do reinforcement toward the right student's response, and to correct the wrong student's response, to make student study much easier, to be their interviewee, mentor, and motivator so that student becomes more active, and to be evaluator toward the learning result done.

c. Support system. Support facility needed in this research is chosen and organized material learning.

d. Instructional and accompanist Impact. Instructional impacts from direct learning model are a student is skilled in combing hair and using face powder without help. Accompanist impacts from this model are a student has the motivation to learn, have the skill to comb hair, can use face powder in daily life, can live autonomously and depends on no other.

Weaknesses found on learning preparation on a restricted trial are a teacher has not planed learning suitable with student's needs and individualize student's obstacle, the teacher cannot control material yet. In learning process, Teachers do not train early childhood match with hair combing training steps and using face powder, there's no repetition on each step done until early mentally disabled childhood can do it by them self without physical help, teachers are not capable to motivate children in the learning process so children have no interests on learning, teachers are not competent to apply the right learning method suitable for each characteristic student's learning obstacle. Learning situation is getting better in the second trial, teachers are able to train early mentally disabled childhood individually, train how to comb hair and to use face powder based on training steps. Each step is repeatedly done until the early mentally disabled child is able to do the task by them without physical help. Teachers are able to train early mentally disabled childhood individually and to motivate them by giving a compliment if students can do their task. Since there is a revision from the previous trial, teachers are competent using material and are able to train students individually regarding students' ability and difficulty, apply method suitable with material and each students' ability and difficulty in learning. The teacher begins to have $79 \%$ positive thought at the end of second restricted trial towards direct learning model, then field trial shows developed learning model get $83 \%$ positive response from teachers. It means the teacher accept and feel the positive impact of learning model application.

\section{CONCLUSION}

The conclusion from this research can be explained as follows: 1. Self-make-up skill learning in extraordinary kindergarten shows that teachers are able to prepare students physically or mentally to study from the beginning. In the main activity, the learning process is less maximal because teachers are not competent using learning material. For 
examples are when the teachers' training to the student is not suitable with students' need, learning obstacle, and ability. Self-Make-up training is not performed step by step. Each step is not performed repeatedly until the student can do it by themselves without physical help, 2) training has not been performed by the teacher, starting from giving full physical help, holding student's hand and doing the task together when a student gets difficulty doing it. 3) Teacher rarely gives rewards to motivate students learning. 4) Teachers do not make a note of every step task which is able to be done or is not able to finish by the students during the lesson. And 4) learning activity is not yet individually done.

2. Developed learning development process starting from the analyses of need and it is supported by various study theory and learning principle.

3. Model development results are :

a. Self-make-up learning model

b. Physical learning model.

\section{REFERENCES}

[1] Arends, Richard I. Learning To Teach. Third Education. United States of America: McGraw-Hill, Inc, 1998.

[2] Abdurrahman, Mulyono. Pendidikan Bagi Anak Berkesulitan Belajar. Jakarta: Rineka Cipta, 2003.
[3] Arum, Wahyu Sri Ambar. Perspektif Pendidikan Luar Biasa dan Implikasinya Bagi Penyiapan Tenaga Kependidikan. Direktorat Jenderal Pendidikan Tinggi, Direktorat Pembinaan Pendidikan Tenaga Kependidikan dan Ketenagaan Perguruan Tinggi. Depdiknas, Jakarta. 2005.

[4] Borg, Walter R \& Gall, MD. Educational Research; An Introduction Fouth Edition. New York Longman, 1989.

[5] Drew, Clifford J. Logan, Donald R. Hardman, Michael L. Mental Retardation a Life Cycle Approach, Third Edition. Columbus Toranto London Syndney: Merrill Publishing Company, 1986.

[6] Dick, Walter and Carey Lau (ed). The Systematic Design of Instruction. Sixth Edition. Boston: Pearson, 2005.

[7] Ichrom, Moch. Sholeh Y.A. Watterdal Magnussonn. Menjadikan Lingkungan Inklusif, Ramah terhadap Pembelajaran (LIRP). Buku 1. Direktorat Pendidikan Luar Biasa Dirjen. Pendidikan Dasar dan Menengah, Depdiknas.UESCO, 2004.

[8] Joyce, Bruce and Weil, Marsha and Calhoun, Emily. Models of Teaching. Eighth Edition. Printed in the USA. : Pearson Education, Inc, 2009.

[9] Rochyadi, Endang dan Alimin, Zaenal. Pengembangan Program Pembelajaran Individual Bagi Anak Tunagrahita. Jakarta : Depdiknas Dirjen Dikti Direktorat pembinaan Pembinaan Pendidikan Tenaga Kependidikan dan Ketenagaan Perguruan Tinggi, 2005.

[10] Runtukahu, J. Tombokan. Analisis Perilaku Terapan untuk Guru. Jogjakarta, Ar-Ruzz Media, 2013.

[11] Reigeluth, Charles M. Instructional Design Theories and Models An Overview of Their Current Status. London, Lawrence Erlbaum Associates, 1983

[12] Moore, Kenneth D. Effective Instructional Strategies From Theory to Practice. New Delhi India: Sage Publications, 2005. 